\title{
CANCELLATION OF LAND OWNERSHIP RIGHTS CERTIFICATE IMPLEMENTED BY THE LAND OFFICE OF BENGKULU CITY
}

\author{
By: \\ Okta Orlando, Hamdani Ma'akir, Herawan Sauni
}

\begin{abstract}
This study aimed to determine the procedure implemented in the cancellation of land ownership certificates implemented by the Ministry of Agrarian Affairs and Spatial Planning/National Land Agency of Bengkulu Province, which was based on the Supreme Court Decision Number: 814K/PDT/2009 that has permanent legal force. The type of study used was juridical empirical legal research with descriptive characteristic, meaning that the research aimed to explain the procedure for the cancellation of a land ownership certificate by looking at the conformity between the applicable legal rules and those applied in the process of canceling a land ownership right. The approach applied in this study was qualitative, which is an analysis that describes the applicable regulations, then linked them to the cancellation of the certificate, the analysis was formed by words based on the technique of collecting and analyzing the relevant data obtained from the implementation of the procedure for cancellation of land ownership rights. While the populations in this study were the litigants and the Ministry of Agrarian Affairs and Spatial Planning/National Land Agency of Bengkulu Province. Primary data collection was carried out by using semi-structured interview technique. Then the primary and secondary data were analyzed by using qualitative descriptive analysis. The results of this study showed that the certificate cancellation had been in accordance with the applicable procedures. Suggestions that can be given were that the cancellation of the certificate of land ownership rights must fulfill all formal requirements in implementing the cancellation of land ownership rights.
\end{abstract}

Keyword: Land Certificate Cancellation 


\section{A. INTRODUCTION}

\section{Research Background}

Cancellation of a land ownership certificate in principle is the cancellation of a state administrative decision as a form of state recognition of the ownership of land of a person that has gone through a series of registration processes as regulated in the applicable laws and regulations, the cancellation of the certificate is carried out among others as the implementation of the court decision that has permanent legal force.

After the cancellation of the land ownership certificate, it is necessary to re-register the land ownership, which is obtained by a person based on a court decision. Whereas the essence of the purpose of land registration is to create legal certainty for interested parties and certainty of rights for land owners. Thus, the purpose of land registration is not only oriented to administrative order but also legal order. ${ }^{1}$ This is to ensure legal certainty for rights holders

1 Herawan Sauni, Konflik Penguasaan Tanah Perkebunan (The Conflict of Plantation's Land Tenure), Ubelaj, Volume 1 Issue 1, October 2016,76, http://ejournal.unib.ac.id, accessed on 15 September, 2017 at 5:23 pm. regarding the physical data and juridical data of a land field. If the legal certainty of land ownership is not guaranteed, it can lead to recurrence of disputes between individuals or conflicts that have a wide impact.

Legal certainty of land rights means that the right holder can take advantage of the land he owns. Given the current conditions where population and industrial growth has jumped drastically, which has an impact on the high need for land field for residential and industrial areas, therefore legal certainty of land rights is needed so that economic growth, security and social society can be maintained. .

In reality, certified land rights are still possible to be challenged in court so that the certainty of who owns the land has to be proven. One example is a case where there are overlapping civil rights over land, with each party has the same ownership to the same plot of land. Overlapping civil rights over land can be caused by various factors as follows, the negligence of land owners who do not carry out their obligations as land owners, namely to cultivate, to utilize their land and 
to maintain the boundary markers of land plots.

The government's objective in implementing land rights registration program is to minimize disputes over ownership/physical control of land plots and prevent land problems. Problems that often occur include were boundary disputes, overlapping land rights, conflicts between companies holding Land Use Rights (abbreviated as $H G U$ in Bahasa) / Building Use Rights (abbreviated as $H G B$ in Bahasa) and communities, land acquisition for public interests and others.

In Indonesia, land registration is regulated in Law Number 5 of 1960 concerning Basic Agrarian Regulations in Article 19 paragraph (1) which reads:

To ensure legal certainty by the Government, land registration is held throughout the territory of the Republic of Indonesia according to the provisions stipulated in a Government Regulation.

As a follow-up to the provisions in Article 19 paragraph (1) of Law Number 5 Year 1960 concerning Basic Agrarian Regulations, the government issued Government Regulation Number:
24 of 1997 concerning Land Registration in which the purposes of land registration are contained in Article 3, they are:

(1) To provide legal certainty and legal protection to the rights holders over a plot of land, apartment units and other registered rights so that they can easily prove themselves as holders of the rights concerned;

(2) To provide information to interested parties, including the government, so that they can easily obtain the data needed to carry out legal actions regarding registered land plots and apartment units;

(3) To maintain an orderly land administration.

As proof that a land right has been registered and is legal according to the law to the holder of the land ownership, a certificate of land rights is given as regulated in Article 32 paragraph (1) which reads:

A certificate is a certificate of proof of rights which is valid as a strong means of proof regarding the physical data and juridical data contained therein, as long as the physical data and juridical data are in accordance with the data contained in the measuring letter and the land ownership book concerned. 
Based on Article 32 paragraph (1) Government Regulation Number: 24 of 1997 concerning Land Registration as mentioned above, it can be concluded that The state provides protection for people's civil rights over land even though, at the location of the land, registration of rights has been carried out and a certificate of ownership to land belonging to other people has been issued. If an administrative flaw is found in the process of registering land rights and there is a court decision that is legally binding on land disputes, the Land Rights Certificate may be canceled / requested to be canceled. As stipulated in the Regulation of the State Minister for Agrarian Affairs / Head of the National Land Agency Number: 9 of 1999 concerning Procedures for Granting Rights to State Land and Management Rights in Article 104 which reads:

(1) Cancellation of land rights includes cancellation of decisions on granting rights, certificates of land rights, decisions on granting rights in the context of regulating land tenure;

(2) Cancellation of land rights as referred to in paragraph (1) is issued because there is an administrative law defect in the issuance of a decision to grant and / or certificate of land ownership or enforce a court decision that has obtained permanent legal force.

Cancellation of the certificate which is carried out according to Regulation of the State Minister for Agrarian Affairs / Head of the National Land Agency Number 9 of 1999 concerning Procedures for Granting Rights to State Land and Management Rights in Article 104, It must also be carefully prepared so as not to rule out that the cancellation that has been carried out will have legal consequences that will result. There are various things that need to be studied / analyzed before a court decision is requested to be followed up by the Ministry of Agrarian Affairs and Spatial Planning / National Land Agency.

To further explore the implementation of the cancellation of a certificate of land rights based on a court decision in a civil case which was implemented by the Ministry of Agrarian Affairs and Spatial Planning / National Land 
Agency of Bengkulu Province Regional Office, there was a request for cancellation by Mrs. Erya Etika (heir of the late H. A. Hanan) to the Head of the Regional Office of the Bengkulu Province National Land Agency through the Head of the Bengkulu City Land Office that was submitted based on a court decision that has permanent legal force based on Supreme Court Decision Number: 814K / Pdt / 2009 November 23, 2009, which in one of the provisions stated that part of the land of the object of the case was the property of the plaintiff where it was contained in Land Ownership Certificate No. 33/s dated on $27^{\text {th }}$ of June 1983 with the area of $19,156 \mathrm{M}^{2}$ with Measuring Letter Number: $470 / \mathrm{PT} / \mathrm{BU} / 1982$ dated on $27^{\text {th }}$ of June 1983 where Mr. Syukri Syukur as the right holder. Based on the request, the Head of the Regional Office of the National Land Agency of Bengkulu Province issued a Decree Number: 51/KEP$17.600 / \mathrm{IV} / 2016$ dated on $28^{\text {th }}$ of April 2016 concerning Cancellation of Land Ownership Certificate Number: $33 / \mathrm{S}$ dated on $27^{\text {th }}$ of June 1983 with the area of $19,156 \mathrm{M}^{2}$ with Measuring Letter Number:
$470 / \mathrm{PT} / \mathrm{BU} / 1982$ dated on $27^{\text {th }}$ of June 1983 where Mr. Syukri Syukur as the right holder.

Based on the description above, the researcher was interested in conducting a study on the cancellation of land ownership certificates carried out by Ministry of Agrarian Affairs and Spatial Planning/National Land Agency of Bengkulu Province along with National Land Agency and the Bengkulu City Land Office, based on a decision in a civil case that has permanent legal force. This decision resolves the case of overlapping ownership of land rights between the parties in the litigation, where a portion of the area stated in the certificate of ownership rights Number: 33/S dated on $27^{\text {th }}$ of June 1983 with the area of $19,156 \mathrm{M}^{2}$ with Measuring Letter Number: 470/PT/BU/1982 dated on $27^{\text {th }}$ of June 1983 where Mr. Syukri Syukur as the right holder has been legally recognized as the belonging of H. A. Hanan.

\section{Identification of problems}

The formulation of the problems raised in this journal was the procedures of implementation of the cancellation of land ownership certificate based on 
Supreme Court Decision Number: $814 \mathrm{~K} / \mathrm{Pdt} / 2009$ which was implemented by Ministry of Agrarian Affairs and Spatial Planning/ National Land Agency (Land Office of Bengkulu City).

\section{B. RESEARCH METHODS}

The research method that researcher applied was juridical empirical where the researcher analyzed various laws and regulations relating to the procedure for the cancellation of land ownership certificates by looking at the suitability between the applicable legal rules and those applied in the process of cancellation of a land ownership. The approach that researcher used in this study was descriptive analysis, namely an analysis of the application or operation of law in the community. ${ }^{2}$

This study used primary data sources / field data and secondary data:

a. Primary data is data that are collected directly from the results of research in the field, in this case the sources were the Ministry of Agrarian Affairs and Spatial Planning / BPN (Regional

2 Jonaedi Efendi, Johnny Ibrahim, Metode Penelitian Hukum Normatif dan Empiris, Prenadamedia Group, Jakarta, 2016, p. 151
Office of the National Land Agency of Bengkulu Province), the Land Office of Bengkulu City. The Informants in this study were:

1. Head of Problem Handling and Land Control Division of the Regional Office of the Ministry of Agrarian and Spatial Planning / BPN of Bengkulu Province.

2. Head of the Section of the Regional Office of the Ministry of Agrarian Affairs and Spatial Planning / $B P N$ Bengkulu Province.

3. Head of Section for Case Handling and Land Control of Bengkulu City Land Office.

4. The disputing parties.

b. Secondary data were obtained from the study of laws and regulations, scientific results and scientific works of scholars related to the material under study.

Data collection was carried out by interview, the interview technique performed was semi-structured or 
semi-standard or free guided interviews.

C. RESULTS RESEARCH AND

DISCUSSION

1. IMPLEMENTATION OF CANCELLATION OF LAND OWNERSHIP RIGHTS AS A FOLLOW-UP OF SUPREME COURT DECISION NUMBER: 814K/PDT/2009

In 1978 (late) H. A Hanan owned a plot of land measuring \pm $100 \times 140 \mathrm{M}^{2}$ which was located in Sukarami Marga Protin IV Village, Talang IV District, North Bengkulu Regency, now in Sukarami Village, Selebar District of Bengkulu City, H. A. Hanan's land came from M Yunus according to the Submission Letter dated on April 15, 1978. Furthermore H. A Hanan's right to land was confirmed by a Certificate dated on February 10, 1981 No. 06/SK/1981 signed by Pesirah Marga Protin IV, Talang IV District, North Bengkulu Regency, now in Sukarami Village, Selebar Subdistrict, Bengkulu City. In 1995 Drs. Syukri Syukur began to cultivate the land he bought from M. Yunus where the location and position of the land was the same as that which M Yunus sold to (late)
H. A Hanan. Because the land was cultivated and controlled by other people, (late) H. A Hanan submitted an objection to Drs. Syukri Syukur and M. Yunus (as the seller). This problem cannot be resolved by deliberation, then the parties take legal channels to resolve the dispute. ${ }^{3}$

Based on the application for the cancellation of the certificate of ownership rights over the land object of the case, the petition has met the formal requirements accompanied by the decision of the Bengkulu Class IA District Court Panel of Judges in Case Number:

14/PDT.G/2007/PN.BKL dated on January 14, 2008 in conjunction with the Bengkulu High Court Judge Council Decision Bengkulu in Case Number: 26/ PDT/2008/PT.BKL dated on $27^{\text {th }}$ of August 2008 in conjunction with Supreme Court Decision Number: 814K/Pdt/2009 dated on $23^{\text {rd }}$ of November 2009 , and the bailiff has executed the execution of the object of the case with evidence of the Minutes of Execution

\footnotetext{
${ }^{3}$ Results of interview with Mrs. Eriya Etika (Heir of H. A. Hanan) on September 8, 2018.
} 
Number:14/BA.Ex.Pdt.G/2007/P

N.BKL. On Thursday, 29

November 2010 an execution was carried out based on the order of the Chairperson of the Bengkulu Class IA District Court according to the determination dated on $16^{\text {th }}$ of November 2010 Number 14/Pdt.G/2017/PN.BK1 in a civil case between :

H. A HANAN

Execution Applicant

Opponent

1. M. Yunus

Execution Respondent I

2. Drs. Syukri Syukur

Execution Respondent II

On the minutes, the party that opponents to execution did not want to sign the Minutes of Execution $^{4}$, Head of the Regional Office of the National Land Agency of Bengkulu Province issued a Decree of the Head of the Regional Office of the National Land Agency of Bengkulu Province Number: 51/KEP-17.600/IV/2016 dated on April 28, 2016 which canceled the

4 Photocopy of Minutes of Execution obtained from the Bengkulu City Land Office
Ownership Certificate No. 33/s dated on June 27, 1983 with the area of $19,156 \mathrm{M}^{2}$ based on Measurement Letter Number: 470/PT/BU/1982 dated on June 27, 1983 on behalf of Syukri Syukur.

As a follow-up to the Decree of the Head of the Regional Office of the National Land Agency of Bengkulu Province Number: 51/KEP-17.600/IV/2016 dated on April 28, 2016, the Head of the Bengkulu City Land Office announced the cancellation matter on Rakyat Bengkulu Newspaper on Friday July 15 2016, within a period of 30 (thirty) days. After the end of the announcement period in the newspaper, it was continued with cancellation and removal of ownership to land Ownership Certificate No 33/s dated on June 27,1983 with the area of $19,156 \mathrm{M}^{2}$ based on Measurement Letter Number: 470/PT/ BU/1982 dated on June 27, 1983 on behalf of Syukri Syukur from the land registration list as a follow-up to the decree. ${ }^{5}$ The related parties will be notified in writing of the

${ }^{5}$ Interview with the Head of the Problem Handling and Land Control Section at the Bengkulu City Land Office (Mr. Eko Budi Kuncoro. $\mathrm{SH}$ ) in the context of research on January 10, 2018, at the Bengkulu City Land Office 
cancellation of the certificate by sending a copy of the cancellation decision. As well as reporting the cancellation of the certificate to Agrarian and Spatial Planning/ Head of the National Land Agency, by attaching the Minutes of Data Processing, Analysis of Decisions which were used as the basis for implementing the cancellation of land ownership certificates.

2. LEGAL CERTAINTY OF CIVIL RIGHT ON LAND OWNERSHIP ASTER THE IMPLEMENTATION OF CANCELLATION OF LAND OWNERSHIP CERTIFICATE NUMBER: 33/S

Issuance of Decree of the Head of the Regional Office of the National Land Agency of Bengkulu Province Number: 51 / KEP-17.600 / IV / 2016 concerning the cancellation of Ownership Certificate No 33 / s dated 27 June 1983 Area 19,156 M2 Measurement Letter Number: 470 / PT / BU / 1982 dated 27 June 1983 an. Thanksgiving. So the evidence of land rights in the form of Freehold Certificate No. 33 / s dated 27 June 1983 Area 19,156 M2 Measuring Letter Number: 470 / PT / BU / 1982 dated 27 June 1983 an. Syukri Syukur has been canceled and declared invalid. As stipulated in Regulation of the Minister of Agrarian and Spatial Planning / Head of the National Land Agency of the Republic of Indonesia Number: 11 of 2016 concerning Settlement of Land Cases Article 24 paragraph 1 (letter b) and paragraph 3 which are as follows:

(1) After receiving the Dispute Resolution Report and The conflict as referred to in Article 23 paragraph (5), Head of Regional Office of BPN or Minister to finish Disputes and Conflicts by publishing:

b. Decision to Revoke Certificate;

(2) The decision to cancel the certificate as referred to in paragraph (1) letter b shall constitute a cancellation of the proof of rights and other general registers relating to said rights, and not the cancellation of the land rights.

Based on the results of an interview with the Head of the Land Problem Handling and Control Division of the Bengkulu Province BPN Regional Office (Mr. Nur Rahmanto, SH, M.Eng.) Said that at the Supreme Court Decree Number: 814K / Pdt / 
2009 where the object of the case was Ownership Certificate No 33 / s dated 27 June 1983 Area 19,156 $\mathrm{M}^{2}$ Measurement Letter Number: 470 / PT / BU / 1982 dated 27 June 1983 Rightsholder Mr. Syukri Syukur, part of the land area of the object of the case was H.A. Hanan's land area of 8,025 $\quad \mathrm{M}^{2}$. Therefore, OwnershipCertificate No. 33 / s dated 27 June 1983 Area 19,156 $\mathrm{M}^{2}$ Measurement Letter Number: 470 / PT / BU / 1982 dated 27 June 1983's. Syukri Syukur has a defect in administrative law because some of the physical and juridical data submitted by the applicant (Mr. Syukri Syukur) in the registration process for the first time a certificate of land ownership is proven based on a court decision which is legally enforceable and remains a civil rights of others.

If a certificate of land ownership is canceled due to legal flaws and/ or implementing a court decision, what is meant by cancellation is the cancellation of proof of ownership of land plots, namely a certificate that has been registered with the Regency / City Land Office, it does not mean that the civil rights of the person over land are nullified, in other words a person is still enownershipd to the land which is the object of the certificate cancellation before a court ruling decides who has the right to own the land plot.

\section{CLOSING}

\section{Conclusion}

1. The implementation of the cancellation of land ownership certificates carried out by the Ministry of Agrarian Affairs and Spatial Planning/ National Land Agency of the Republic of Indonesia (Kanwil BPN of Bengkulu Province and the Land Office of Bengkulu City) based on court decisions that have legal force must still meet the applicable administrative requirements and procedures so that the decisions made did not turn to be legally disabled;

2. For the land plot of which the land ownership certificate that had been canceled, there were civil rights over the land plot of the two parties in the case, which was based on the injunction of the court's decision has permanent legal force;

3. The parties who already have land rights based on a court 
decision that is legally enforceable can still register the land they own to issue a certificate of land ownership.

\section{Suggestion}

1. In implementing the cancellation of a certificate of ownership rights over land based on a court decision that has permanent legal force, it is necessary to pay attention to the warning that the implementation does not exceed the verdict, so that it will not harm a person's the civil rights over a land.

2. It is necessary to regulate the cancellation of the certificate of ownership over land as well as to improve the certificate which is the object of the cancellation where it is evident that there are administrative defects in several parts of the land ownership rights to guarantee civil rights over land.

\section{REFERENCES}

Adrian Sutedi, (2014), Sertifikat Hak Atas Tanah, Sinar Grafika, Jakarta.

Arie Sukanti Hutagalung dan Markus Gunawan, (2009), Kewenangan Pemerintah Di Bidang
Pertanahan, Rajawali Pers, Jakarta.

Badan Pertanahan Nasional RI, (2013), Anotasi putusan Pengadilan Mengenai Pertanahan Jilid 2 (Tata Usaha Negara), Pusat Hukum dan Hubungan Masyarakat, Jakarta.

Bernard L. Tanya,Yoan N. Simanjuntak dan Markus Y. Hage, ( 2013), Teori Hukum Strategi Tertip Manusia Lintas Ruang dan Generasi, Genta Publishing, Yogyakarta.

Boedi Harsono, (2016), Hukum Agraria Indonesia Sejarah Pembentukan Undang-Undang Pokok Agraria, Isi dan Pelaksanaannya, Penerbit Universitas Trisakti, Jakarta.

Darwin Ginting, (2010), Hukum Kepemilikan Atas Tanah Bidang Agribisnis, Ghalia Indonesia,Bogor.

Farida Fitriyah, (2016), Hukum Pengadaan Tanah Transmigrasi, Setara Press, Malang.

Farida Widyartati, (2016), Tindak Lanjut Pelaksanaan Putusan Pengadilan, Pusdiklat Kementerian Agraria dan Tata Ruang/Badan Pertanahan Nasional, Jakarta.

Florianus SP Sangsun, (2007), Tata Cara mengurus Sertipikat Tanah,Transmedia Pustaka, Jakarta.

Gunanegara, (2017), Hukum Pidana Agraria Logika Hukum Pemberian Hak Atas Tanah dan Ancaman Hukum Pidana, Tatanusa,Jakarta.

H.M. Arba, (2015), Hukum Agraria Indonesia, Sinar Grafika, Jakarta. 
Hotman Pardomuan, (2016), Masalah dan Sengketa Hak atas Tanah, Pusdiklat Kementerian Agraria dan Tata Ruang/Badan Pertanahan Nasional, Jakarta.

Jw.Muliawan, (2009),Pemberian Hak Milik Untuk Rumah Tinggal, Cerdas Pustaka, Jakarta.

Philupus M.Hadjon, (1995), Pengantar Hukum Administrasi Indonesia, Gajah Mada University Press. Yogyakarta.

Rusmadi Murad, (2013), Administrasi Pertanahan Pelaksanaan Hukum Pertanahan dalam Praktek, Mandar Maju,Bandung.

Sarwono, (2012), Hukum Acara Perdata Teori dan Praktek, Sinar Grafika, Jakarta.

Sudikno Mertokusumo, (2002), Hukum Acara Perdata Indonesia, Liberty, Yogyakarta.

Widhi Handoko, (2014), Kebijakan Hukum Pertanahan Sebuah Refleksi Keadilan Hukum Progresif, Thafa Media,Yogyakarta.

\section{Website}

Ali Samiun, Macam - Macam Putusan Pengadilan, http://www.i nformasiahli. com/2015/08/macam-macamputusan-pengadilan.html, diakses tangal 11/10/2017, 20:15 WIB.

Herawan Sauni, Konflik Penguasaan Tanah Perkebunan (The Conflict Of Plantation's Land Tenure), Ubelaj, Volume 1 Issue 1, Oktober 2016, http://ejournal.unib.ac.id, diakses tanggal 15 September 2017, Pukul 17:23 WIB.
Redaksi, Putusan Pengadilan, http://kbbi.kata.web.id/putusanpengadilan/, diakses tanggal 08 Oktober 2017, pukul 18 : 22 WIB

Redaksi, Macam-Macam Putusan Hakim, http://www. suduthukum.com/ 2016/03/ macam-macam-putusanhakim.html' diakses tanggal 11 Oktober 2017 pukul 18 : 30 WIB

Soerjono Soekanto, Pengantar Penelitian Hukum dalam http:// teguhalexander. blogspot.co.id /2008/ 12/ kriteria- putusanhakim- yang-ideal.html, diakses tanggal 11 oktober 2017, pukul 10 : 36 WIB.

Yance Arizona, Apa Itu Kepastian Hukum, https:// yancearizona.net /2008/04/13/ apa-itu-kepastianhukum/, diakses tanggal 11 Oktober 2017, pukul 11: 14 WIB

\section{Journal}

Jurnal Pertanahan, ISSN 0853-1676, Volume 4, Nomor 1, Mei 2014. Pusat Penelitian dan Pengembangan Badan Pertanahan Nasional Republik Indonesia.

\section{Regulation}

Undang - Undang Dasar Negara Republik Indonesia Tahun 1945.

Kitab Undang - undang Hukum Perdata

Undang - undang Nomor : 5 Tahun 1960 Tentang Peraturan Dasar Pokok Pokok Agraria.

Peraturan Pemerintah Nomor : 24 Tahun 1997 Tentang Pendaftaran Tanah.

Peraturan Menteri Negara Agraria/Kepala BPN Nomor : 3 Tahun 1997 
Tentang Ketentuan Pelaksana

Peraturan Pemerintah Nomor : 24

Tahun 1997 Tentang Pendaftaran

Tanah.
Peraturan Menteri Negara Agraria/
Kepala Badan Pertanahan
Nasional Nomor : 9 Tahun 1999
Tentang Tata Cara Pemberian
Dan Pembatalan Hak Atas Tanah
Negara Dan Hak Pengelolaan.

Pertauran Kepala Badan Pertanahan

Nasional Republik Indonesia

Nomor : 2 tahun 2013 Tentang

Pelimpahan Kewenangan

Pemberian Hak Atas Tanah Dan

Kegiatan Pendaftaran Tanah

Peraturan Menteri Agraria Dan Tata

Ruang / Kepala Bandan

Pertanahan Nasional Republik

Indonesia Nomor : 11 Tahun 2016

Tentang Penyelesaian Kasus

Pertanahan. 